\title{
Correction to: Dynamics of serum antithyroglobulin antibodies in patients with differentiated thyroid cancer
}

\section{Fernanda Bueno ${ }^{1} \cdot$ María Gabriela García Falcone ${ }^{1} \cdot$ Mirna Angela Peñaloza ${ }^{1}$ Erika Abelleira ${ }^{1} \cdot$ Fabián Pitoia $^{1}$}

Published online: 14 September 2020

(c) Springer Science+Business Media, LLC, part of Springer Nature 2020

Correction to: Endocrine

https://doi.org/10.1007/s12020-019-02112-7
The original version of this article unfortunately contained a mistake in Table 3. The initial levels of $\mathrm{Tg} \mathrm{Ab}$ was incorrectly transcribed. The corrected Table 3 is given below.

The original article can be found online at https://doi.org/10.1007/ s12020-019-02112-7.

\section{Fabián Pitoia}

fpitoia@intramed.net

1 Division of Endocrinology, Hospital de Clínicas-University of Buenos Aires, Buenos Aires, Argentina 
Table 3 Baseline characteristics and comparison of the responses to therapy in patients with detectable $\mathrm{TgAb}$ with and without radioiodine remnant ablation

\begin{tabular}{|c|c|c|c|}
\hline & \multicolumn{2}{|c|}{$\begin{array}{l}\text { Radioiodine remnant } \\
\text { ablation (RA) }\end{array}$} & \multirow[b]{2}{*}{$p$} \\
\hline & $\begin{array}{l}\text { Without RA } \\
(n=23)\end{array}$ & $\begin{array}{l}\text { With RA } \\
(n=30)\end{array}$ & \\
\hline \multicolumn{4}{|l|}{$\operatorname{Sex}(n, \%)$} \\
\hline Female & $18(78.3)$ & $27(90)$ & \multirow[t]{2}{*}{$0.237^{\mathrm{a}}$} \\
\hline Male & $5(21.7)$ & $3(10)$ & \\
\hline \multicolumn{4}{|l|}{ Age (years) } \\
\hline Median (range) & $42(27-69)$ & $44(29-76)$ & $0.2697^{\mathrm{b}}$ \\
\hline \multicolumn{4}{|l|}{ Histology $(n, \%)$} \\
\hline Papillary & $22(95.7)$ & $30(100)$ & \multirow[t]{2}{*}{$0.249^{\mathrm{a}}$} \\
\hline Follicular & $1(4.3)$ & 0 & \\
\hline Lymphocytic thyroiditis $(n, \%)$ & $17(73.9)$ & $14(46.7)$ & $0.741^{\mathrm{a}}$ \\
\hline Initial $\mathrm{TgAb}$ median IU/ml (range) & $194(0-2000)$ & $98(0-1180)$ & $0.1435^{\mathrm{b}}$ \\
\hline \multicolumn{4}{|l|}{$\operatorname{TgAb}$ trend at 12 months $(n, \%)$} \\
\hline Undetectable & $5(21.7)$ & $1(3.3)$ & \multirow[t]{5}{*}{$0.006^{\mathrm{a}}$} \\
\hline Decreased & $14(60.9)$ & $15(50)$ & \\
\hline Stable & $1(4.3)$ & $6(20)$ & \\
\hline Increased & $3(13)$ & $2(6.7)$ & \\
\hline Unknown & 0 & $6(20)$ & \\
\hline \multicolumn{4}{|l|}{ Initial response to treatment $(n, \%)$} \\
\hline Excellent response & $8(34.8)$ & $7(23.4)$ & \multirow[t]{4}{*}{$0.610^{\mathrm{a}}$} \\
\hline Indeterminate response & $15(65.2)$ & $21(70)$ & \\
\hline Biochemical incomplete & 0 & $1(3.3)$ & \\
\hline Structural incomplete & 0 & $1(3.3)$ & \\
\hline \multicolumn{4}{|c|}{ Clinical status at 36 months of follow up } \\
\hline $\operatorname{NED}(n, \%)$ & $8(34.8)$ & $9(30)$ & \multirow[t]{4}{*}{$0.442^{\mathrm{a}}$} \\
\hline Indeterminate $(n, \%)$ & $15(65.2)$ & $19(63.3)$ & \\
\hline Biochemical incomplete $(n, \%)$ & 0 & 0 & \\
\hline Structural incomplete $(n, \%)$ & 0 & $2(6.7)$ & \\
\hline \multicolumn{4}{|l|}{ Time to undetectable $\mathrm{TgAb}$ (months) } \\
\hline Median (range) & $11.25(6-21)$ & $16(11-36)$ & $0.0232^{\mathrm{b}}$ \\
\hline \multicolumn{4}{|l|}{ Time of follow-up (months) } \\
\hline Median (range) & $27(16-42)$ & $82(27-210)$ & \\
\hline
\end{tabular}

$R A$ radioiodine remnant ablation, $T g A b$ anti-thyroglobulin antibodies, $N E D$ no evidence of disease

${ }^{\mathrm{a}} p$ values were determined by the $\chi^{2}$ test

${ }^{\mathrm{b}} p$ values were determined by the Mann-Whitney $U$ test 